Article

\title{
Investigating Environmental Transgressions at Corbett Tiger Reserve, India
}

\author{
Tanmay Sharma ${ }^{1}$, Joseph S. Chen ${ }^{1}$ and Wan-Yu Liu ${ }^{2, *} \mathbb{C}$ \\ 1 Department of Recreation, Park, and Tourism Studies, Indiana University, 1025 East 7th Street, Bloomington, \\ IN 47405, USA; tasharma@indiana.edu (T.S.); joechen@indiana.edu (J.S.C.) \\ 2 Department of Forestry, National Chung Hsing University, 145 Xingda Rd., South Dist., \\ Taichung City 40227, Taiwan \\ * Correspondence: wyliu@nchu.edu.tw; Tel.: +886-4-2285-0158
}

Received: 9 September 2019; Accepted: 3 October 2019; Published: 17 October 2019

\begin{abstract}
Through a qualitative lens involving both in-depth interviews and focus groups, this research attempts to probe the issues of environmental transgressions caused by tourists and tourism providers in one of the oldest and largest national parks in India, the Corbett Tiger Reserve (CTR), Uttrakhand. It reveals that even though tourism stakeholders are conscious of environmental transgressions, concrete efforts towards environmentally sustainable practices in CTR do not seem to be a priority. Nevertheless, this research suggests that visitor's noncompliant behavior may be altered by enhancing place attachment through repeat visitations, improving visitor experiences, and effective information dissemination. Also, future tourism operations may require a reduction in environmental transgressions through the creation of an agency that can assist community-based tourism operations.
\end{abstract}

Keywords: place attachment; deviant behavior; environmental transgression; Indian national parks

\section{Introduction}

Before Indian independence, protected areas were designated hunting reserves for British nobility [1]. After 1947, along the lines of the American Yellowstone conservation model, these areas were rechristened as national parks and set aside for wilderness conservation [2]. After following the agenda of securing undisturbed wilderness for a couple of decades, nature-based tourism in national parks became a priority area for the government only in the recent past [3]. Non-consumptive tourism provided the economic reasoning for wildlife conservation and was also championed as a welfare tool for uplifting the local communities [4,5]. This push for tourism development was based on the premise that observation of animals in their native habitats was a non-consumptive use of nature with minimal ecological impact [6]. However, due to a burgeoning population, in recent years national parks have started receiving visitors year-round, and park authorities have been left tackling the adverse impacts of increased visitations, including environmental transgressions [7]. Environmental transgressions are regarded as noncompliant with conservation rules that involve breaking environmental protection laws and disregarding environmental norms of behavior. These antienvironmental actions encompass both noncompliant visitor behavior and unsustainable development strategies implemented by local tourism providers [8-10].

Visitors in Indian national parks are regulated through "passive or soft visitor management tools that are limited to dos and don'ts" which achieve little success towards minimizing the environmental impacts of nature-based activities [11,12]. Based on recent trends, it is predicted that the increasing middle class is likely to generate future demand for nature-based tourism in India national parks [3]. As a result, experts have begun to advocate limiting visitor numbers and even imposing an outright 
ban on tourist activities in Indian national parks [13]. Conversely, even though the magnitude of the littering problem at iconic natural sites is largely a result of rapidly increasing levels of visitation, drastically reducing the number of visitors might not be entirely feasible in a country with such a large population.

While deviant visitor behavior has caused ecological damage inside protected areas, expanding demand for wildlife-human interactions has triggered rapid commercialization of spaces in the immediate vicinity of the parks, further diminishing the beauty of a destination. At the cost of violating ecological thresholds, local tourism providers have been engaged in self-regulated destination development, which has led to unplanned urban sprawl, land and property encroachment, and concomitant waste generation and improper disposal [14,15].

In view of the environmental degradation due to the influx of tourists to protected areas, tourism scholars have suggested a need for future phenomenological research to explore attitudes and opinions of the tourists and local tourism providers regarding reducing environmental transgressions in natural settings $[16,17]$.

With the paucity of tourism literature on environmental transgressions in emerging economies, this phenomenological study aims to explore tourists' attitudes and behaviors towards the oldest and largest national park in India, the Corbett Tiger Reserve (CTR), Uttrakhand, India. Specifically, this study investigates the perceptions of tourism stakeholders (i.e., tourists, local tourism providers, local residents, nongovernmental organizations (NGOs), and local authorities) regarding environmental transgressions and factors hindering environmentally sustainable practices. The resultant data may assist tourism professionals in developing strategies to cope with the issues of environmental transgressions. Meanwhile, it may also evoke a conceptual framework to guide future studies on environmental transgressions.

\section{Review of Literature}

\subsection{Deviant Tourist Behaviors}

Avoiding the harmful impacts of tourism on national parks is a global challenge. Policymakers are looking for ways to minimize those impacts. Pickering and Hill [18] stated that increased park visitations cause pressure on visited habitats, threaten endangered species, and affect soil properties. Park trails maintained for off-roading crisscross the habitat areas of endangered species, and the presence of tourists causes alterations in habitat structures leading to temporary or permanent habitat loss [19]. As per Esfandiar, Dowling and Pearce [20] and Hu, Zhang, Wang, Yu, and Chu [21], many of these 'new' tourists originate from urban areas where a civic body is responsible for removal of rubbish and maintenance of green spaces. Occasionally, tourists unknowingly cause ecological impacts when they break the rules at holiday destinations. It highlights the ignorance of their role in preserving the sanctity of the wilderness. Dawson, Hendee, and Schuster [22] observed that these violations are committed carelessly by tourists without fully realizing their repercussions. It implies that it is possible individuals might possess environmental awareness but still display deviant behavior.

While environmental transgressions may harm both the environment and human beings, the negative consequences of these detrimental actions are not always immediate or indeed evident. Moreover, these acts are not universally perceived as illegal, or reprehensible, and perpetrators mostly never get penalized for indulging in deviant behavior. For example, transgressions such as alighting from vehicles in designated areas, consumption of alcohol, using mobile devices, and causing damage to flora and fauna are commonly committed in Indian national parks with very few prosecutions and penalties [7].

Frost, Laing, and Beeton [23] highlighted that historically, consumption and co-existence with nature is strongly embedded in the cultural and religious ethos of Asian societies. They suggested that the current abuse of natural attractions by the rising affluent and educated middle class might be a result of this strong connection where they look at nature purely as a resource available for their 
consumption. As Asian societies have traditionally been respectful towards the environment, Wolf, Stricker, and Hegenloh [24] discussed the need to counter noncompliant behavior by focusing on the cultural and spiritual importance of wilderness. Hernandez et al. [16] investigated the impact of place attachment in an individual's decision to break environmental laws and link place attachment with ecological variables such as environmental attitudes and minimizing environmental transgressions. Similarly, Kollmuss and Agyeman [25] also reckoned that an individual's decision to either follow or break the rules might be connected to the person's levels of attachment with the surroundings.

\subsection{Place Attachment}

Place attachment is a "socio-psychological concept which describes the emotional-symbolic-functional attachment" of a person to a particular geographical location and has several dimensions such as place association, place identity, place belongingness, and so on [26-30]. Ramkissoon, Weiler, and Smith [31] linked place attachment with the extent to which individuals associate themselves with an environmental setting and indulge in sustainable tourist behavior. Recently, researchers have focused on the impacts of place attachment on tourist behaviors. Zelenski, Dopko, and Capaldi [32] supported the possibility that exposure to nature could build a bond between wildlife and tourists and act as the antecedent to the reduction in deviant behavior.

Seamon [33] examined place attachment amongst tourists through a phenomenological lens and suggested that such attitudes often emerge from lived experiences and the fulfillment of specific goals culminating into contentment and loyalty. Place attachment may be affected by the travel distance. For example, the further away tourists are from their city, neighborhood, or home, the lesser the place attachment could be [34]. It might explain why the likelihood of tourists indulging in deviant behavior is high in locations far away from their place of residence, as the absence of community and social pressures might lead them to have a more relaxed attitude and reduced awareness of risks. Serenari, Leung, Attarian, and Franck [35] confirmed this claim that the lack of social pressure could be one of the most significant barriers in preventing environmentally destructive behavior by tourists. Looking at some potential advantages of place attachment, Payton, Fulton, and Anderson [36] suggested that a secure attachment to a place could serve as a means of uniting individuals and groups for an environmental and social cause and altering their behavior, which explains why residents of a specific location often come together to clean up their neighborhood.

Morgan [37], observing the developmental process through which place attachment is embedded in an individual, found that place attachment emerges from childhood experiences. Gifford and Andreas [38] pinpointed that personal and social factors influence place attachment and environmental concerns. Lee [39] suggested that place attachment is also likely to enhance the conservation commitments of individuals and increase the likelihood of environmentally responsible behavior among tourists. Through their work, Toudert and Bringas-Rabago [40] focused on the correlation between familiarity with the destination through repeat visitations and positive transformation of impressions towards the visited location. They suggested that, as environmental motives and attachment are inculcated over time, a single/brief nature exposure is not likely to permanently alter a person's attitude or behavior. Buta, Holland and Kaplanidou [41] stated that place attachment could be enhanced through proenvironmental civic engagements, education, and communication. Similarly, Zhang, Zhang, Zhang, and Cheng [42] suggested that since place attachment has a substantial impact on tourist behavior, this phenomenon could be utilized in developing education programs to positively influence visitors' attitudes.

\subsection{Sustainable Practices in Tourism}

Nature-based tourism destination images and attractiveness are inextricably dependent on well-preserved resources in the destination environment [43]. As growing demand for human-wildlife interaction leads to the emergence of a wide range of nature-based tourism activities around national parks, acquisition of an iconic tourism destination status also accelerates the process of commodification 
that threatens the long-term environmental health of destinations [17,44]. Because of the rising concerns regarding the detrimental environmental impacts of tourism development on destinations, environmentally sustainable practices have become a focus of discussion for policymakers only in the recent past [45]. Sustainable development signifies and incorporates a "set of principles, policy prescriptions, and management methods" that plot a tourism development strategy to safeguard the indispensable ecosystem for future development [46]. The concept provides a "unified platform where tourism stakeholders can interact, negotiate, and reflect on the consequences of their actions on the environment" [47].

The concept of sustainable practices advocates the acknowledgment of limits to tourism growth amongst key stakeholders, especially local tourism providers [48]. In developing countries, most governmental institutions are unable to control the pace of tourism development, which runs into the hands of influential local stakeholders, such as private businesses [49]. The eagerness of local providers to make the most of the tourism boom surpasses the willingness of tourism developers and local authorities to monitor and organize the tourism sector [14]. Consequently, the principles of sustainable tourism development are not well understood and implemented, as tourism infrastructure development predominantly remains confined to increasing bed capacities only [50].

As evidenced by mushrooming hotels in up-and-coming tourism destinations, this unregulated tourism development contributes to a treacherous building overload, resulting in the misuse of natural resources such as water and forests [51]. The current unplanned urban sprawl is indicative of local stakeholder's blatant disregard for ecological thresholds, resulting in irreversible environmental damages [3]. This insatiable urge to grow results in hotels and restaurants inappropriately disposing large quantities of garbage, including soft drink bottles and polyethylene bags in open dumps, sewers, and open channels, adversely affecting the ecosystem and diminishing a destination's image [7,52]. Tourism planning literature has highlighted the absence of strategic tourism planning by local government and the lack of coordination amongst local stakeholders as the primary barrier in implementing sustainable tourism management and reducing environmental transgressions around protected areas $[53,54]$.

\section{Materials and Methods}

Corbett Tiger Reserve (CTR), the oldest and largest national park in India, is located in the northern state of Uttrakhand about $250 \mathrm{~km}$ north-east of New Delhi (Figure 1). Situated in the western Himalayan foothills, CTR was established as the first national park of India in 1936 and later declared a tiger reserve in 1997. The park now includes a total area (including buffer zones) of $1318 \mathrm{~km}^{2}$, and according to the last tiger census in 2014, it has recorded the highest concentration of wild tigers in the world [55].

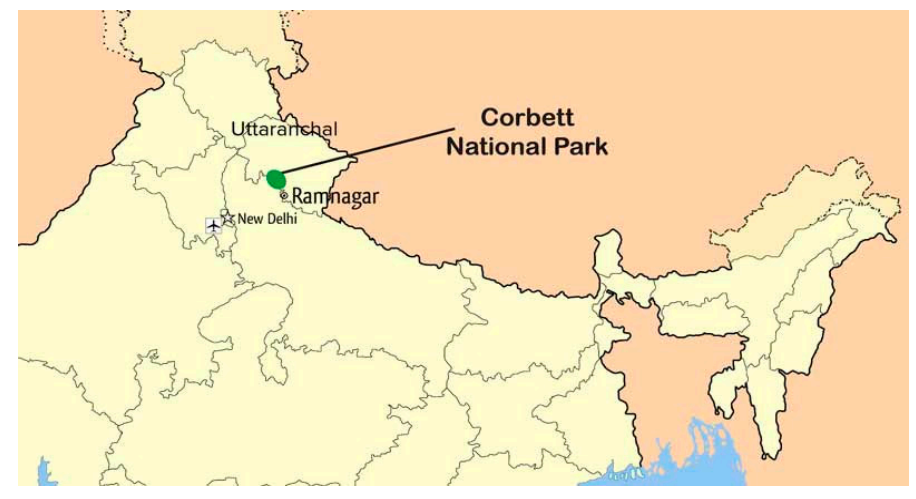

Figure 1. Corbett Tiger Reserve (CTR) location (own research).

Tourism activities in and around CTR were developed on a commercial basis in the 1990s, and luxury resorts catering to international and domestic tourists were subsequently built by private 
tourism providers [56]. CTR was selected as the study site since it is a popular wildlife tourism destination and is experiencing positive growth in the number of tourists, with the majority of these tourists being Indian citizens [3,57]. Over the years, CTR has witnessed unprecedented tourist influx, with the number of tourists increasing from 29,000 per year in 1986-1987 to 245,000 tourists in 2014-2015 [58].

Stakeholders are 'social actors' who undertake one or more activities in a system; these could be individuals or social entities that are capable of undertaking and defending critical decisions [59]. As efficient and effective stakeholders are bound to play a vital role in undertaking much needed systemic interventions towards reducing environmental transgressions, it was vital for the study to determine who managed or participated in the tourism scene at CTR. To identify stakeholders, researchers with prior experience working at CTR were consulted. In addition, before initiating fieldwork, local NGO representatives were consulted to list out other potential stakeholders until no new stakeholders could be identified. This study involved four different types of tourism stakeholders: (1) tourists, (2) local tourism providers, (3) local residents, and (4) NGOs and local authorities.

Data were generated through two methods: (1) personal interviews and (2) focus groups. To gain a holistic perspective on environmental transgression, a total of 40 interviews were conducted along with two focus group surveys consisting of 10 participants each. All interviews and focus groups were audio-taped with participants' informed consent, and convenience sampling was used for recruiting volunteer interviewees.

The interviewees comprised 10 local tourism providers, 10 residents, 10 tourists, and 10 local government officials/nongovernmental organization (NGO) representatives. The duration of the personal interview was less than $30 \mathrm{~min}$. Concerning the construction of the list of interviewees, the names of tourism providers were compiled via help from a local travel agency. Also, a list of hotels available online was utilized, and the owners/managers of hotels and restaurants were identified and approached for interview. These local tourism providers further supported in shortlisting visitors/tourists for in-depth interviews and focus group surveys. The tourists were invited to participate in the interview at the park's rest area and hotel lobbies. To identify community leaders and government officials/NGO representatives, help was taken from a local NGO (i.e., the Corbett Foundation) whom the research team contacted beforehand. Also, social media tools such as Facebook and Trip Advisor were used to obtain additional information from tourists who had visited CTR. The residents were approached at the town center, and the research team sought the help of local community leaders in recruiting additional local residents for in-depth interviews and focus group discussions.

For the focus group surveys, the informants in the focus groups were also selected through a reference from the interviewees. Afterward, the research team contacted the potential study subjects to hold focus group meetings in a local restaurant. Glaser and Strauss [60] recommended the concept of saturation for achieving an appropriate sample size in qualitative studies. In this study, it was felt that after interviewing 10 stakeholder representatives, the study did not result in additional perspectives or information, and that 'saturation' was achieved. Bernard [61], suggested that "10-20 knowledgeable people are enough to uncover and understand the core categories in any well-defined cultural domain or study of lived experience", and Boddy [62] also recommended an upper limit of 30 in-depth interviews if researching a relatively homogeneous population. Similarly, Creswell $[63,64]$ proposed a sample of 5 to 25 interview respondents as adequate for a phenomenological study. Hence, a sample size of 40 was deemed sufficient for data analysis.

Since confronting environmental transgressions needs a joint effort encompassing all stakeholders, it was critical to record the different attitudes and opinions of all stakeholders vis-à-vis each other's actions or inactions around CTR. While the perspective of each stakeholder group was separately recorded through personal interviews, it was felt that a forum should be provided where all stakeholders could be brought together to discuss the reasons behind environmental transgressions at CTR. As suggested by Ray [65], phenomenological studies usually focus on a group of between 8 and 
12 people; hence, as part of this study, 2 focus group discussions were conducted with 10 participants each ( 3 tourists, 3 local tourism providers, 3 local residents, and 1 NGO/local official). Interviews and focus groups in Hindi or English, depending on the preference of the participants, were deployed to allow the participants to speak freely and to allow for new issues to emerge during discussions.

Meanwhile, the following open-ended questions were asked as part of the study:

- What is the stakeholders' opinion regarding nature tourism at CTR?

- What are the attitudes/behaviors toward and the experience of CTR?

- How can environmental transgressions be confronted in and around CTR?

- What types of tourism development strategies are being followed around CTR?

Since a phenomenological approach should ideally be less structured and more in-depth during the collection stage, these questions aimed at exploring the perspectives of respondents by collecting opinions using less structured and more flexible questions from respondents sharing similar lived experiences. Qualitative data were collected between June and July 2016. To obtain their views on environmental transgressions being committed in and around CTR, participants were asked open-ended questions, and all responses were summarized initially by three researchers. To validate the interviews, thematic analysis was deployed to obtain emerging themes put forth by respondents. During the investigation, three researchers made notes and put the resultant data into conceptual categories. These researchers supported the data analysis process and helped in enhancing the trustworthiness of the analysis by reaching a consensus on critical themes that appeared from the fieldwork. The study also attempted to address the commonly cited limitations of qualitative research by following a triangulated research design and replicable analytical processes [66]. To enhance the reliability, this study verified transcripts and conducted follow-ups for clarifications with key informants after six months of doing the interviews through telephone calls to the interviewees, for which consent was obtained at the time of the interviews and focus group discussions [67].

\section{Results}

This study yielded four overarching themes concerning (1) turmoil in tourism development, (2) tourists' attitudes toward CTR, (3) tourists' behaviors toward CTR, and (4) environmental transgressions. To further illustrate the emerging themes, the following section highlights specific points that emerged from the study.

\subsection{Turmoil in Tourism Development}

Resort development surrounding CTR is rather intense, which threatens the ecosystem, as the development is uncontrolled. A senior local World Wildlife Fund (WWF) coordinator reckoned: "In addition to the highest concentration of tiger, CTR also has the highest concentration of tourist resorts found anywhere around a forest in India. Nobody keeps a count, but there are at least 100 properties in business, and new ones are coming up every season. Over the past decade, the encroachment of peripheral forestland and blocking of wild animals' access to water bodies and adjoining forests has become routine along the Ranikhet road on CTR's eastern boundary" (interview participant \# 22).

Upon completing their morning/evening safari, most tourists head back to their resorts, which are located at the edge of the park in Dhikuli. Dhikuli, the central tourism hub, is a $4-5 \mathrm{~km}$ stretch strewn with hotels, resorts, parking lots, and landscaped gardens on the outskirts of CTR. Traffic congestion has been a concern affecting the tourist experience as a resident pinpointed: "Excess amounts of motor vehicles are driven into the park causing traffic congestion in CTR area, as you can see, the road in Dhikuli is bustling and impatient drivers unnecessarily honk and drive rashly" (focus group participant \# 9).

Several respondents rendered suggestions to cope with the negative impacts caused by tourism development. A prominent resort owner mentioned: “Tourists coming from Delhi are rich and so they should be asked to pay fees over the nominal ones currently being charged. These fees should be earmarked into eco-development funds" (interview participant \# 01). Another concerned restaurant 
owner stated: "Since CTR has been witnessing high tourist influx, tourists should be given limited access to the park and should stay only on designated roads. Mandatory guides should record any deviant behavior and perpetrators should be 'named and shamed' and not allowed to re-enter CTR" (interview participant \# 02).

Further, a resident felt that the park authorities should develop tourism in buffer areas to increase vigilance there and to take pressure away from the central attractions. "Tourism growth has created jobs, hence instead of restricting visitor numbers, park authorities should plan for effective dispersion of tourist pressure and regulation of tourist behavior" (focus group participant \# 3).

\subsection{Tourists' Attitudes toward CTR}

The respondents were generally unaware of the legacy of the park and Jim Corbett, the conservationist after whom CTR was christened, which indicated a low level of expressed place attachment. Toudert and Bringas-Rabago [40] stated visitation patterns also impact place attachment. Since tourists are permitted inside the park only for a short duration of 2-3 h, respondents are unable to associate themselves with the prestigious institution. In line with the literature, a first-time visitor to CTR stated: "I've only been to CTR once and that too for a short duration, so I haven't developed an affinity to it yet, not like with nearby tourist attractions like Nainital or Ranikhet. I think the more you visit a place, the more it becomes a part of you and the more likely you are to fight for its preservation" (interview participant \# 30).

Stakeholder responses also indicated that tourists who lived closer to CTR might have more positive attitudes than those visiting from distant cities. Precisely, tourists living closer to CTR understood the importance of the park towards income generation for the local community and overall economic impact on the region. Interestingly, almost all tourists approached as part of the study undermined the acquisition of environmentally friendly beliefs and behaviors and were of the opinion that changes in behavior on a personal level would have an insignificant impact on the huge problems of littering and environmental degradation. A visitor from New Delhi mentioned: "OK I will stop littering ... (but) will that solve the problem and make India clean?" (focus group participant \# 2).

Interestingly, stakeholders observed that wealthy tourists might demonstrate higher proenvironmental actions but not necessarily heightened environmental concern. This means that tourists to CTR might be interested in paying a higher park entrance fee but might not necessarily be attached to CTR or abstain from indulging in deviant behavior. Similar to past research, younger people approached as part of the study (i.e., less than 25 years of age) expressed higher levels of place attachment, and education appeared to be an essential factor driving knowledge and positive attitudes towards CTR [41]. A tourist visiting from Delhi shared: "Formal education is important for participation in environment-friendly activities such as sustainable tourism and sustainable use of resources" (interview participant \# 28).

Also, respondents believed that being a member of social groups (religious sects, resident welfare associations, etc.) could be linked to positive attitudes towards the environment. Such social membership generally drove a more positive attitude towards protected areas and a stronger motivation to participate in proenvironmental behavior. Another tourist mentioned: "My social group (Art of living) reflect higher levels of integration of individuals into their respective communities and environment, which in turn facilitates in a better exchange of information, adherence to norms and sanctions, and contributes to a higher trust in authorities" (interview participant \# 35).

\subsection{Tourists' Behaviors toward CTR}

The Uttrakhand forest department controls and regulates tourism activities inside CTR. During the tourist season, tourist traffic entering CTR is regulated with a system of advance reservations that need to be obtained from the forest department office located at Ramnagar (township adjacent to CTR boundary). Visitor groups, along with licensed nature guides and jeep drivers (who accompany tourists on a rotational basis) are allowed to enter the reserve only for a few hours [52]. During the 
tourist season (November to June), wildlife viewing occurs twice in a day (i.e., between 6-10 am and 4-6 pm). At the entrance, four to five tourists are assigned a vehicle with a local driver and a nature guide. Each day, using two designated entry/exit points, up to 150 vehicles carrying approximately 600 tourists enter CTR. A forest guard mentioned: "During peak season, there is chaos at the booking office and all the attention and efforts of park officials are diverted towards dealing with tourist issues" (interview participant \# 25).

Tourists are allowed to carry food, water bottles, and mobile phones in a bag, and before embarking on the trip, they are given a haphazard and vague briefing by a nature guide and forest guard on environmental safekeeping inside CTR (Figure 2). Throughout the journey, many tourists are seen littering in the park, arguing with the staff to allow them to enter the restricted core area or for deviating from the prescribed route. Some tourists also attempted to alight from their vehicle, often leading to arguments and confrontations between the tourists and guides/drivers. During the safari, the accompanying guide and driver are repeatedly cajoled by tourists to ensure tiger sighting. Once a tiger is sighted, the information is swiftly relayed to each other by drivers and guides active in the area through mobile phones, and in a matter of minutes, more than 50 vehicles converge at that spot to catch a glimpse of the animal (Figure 3).

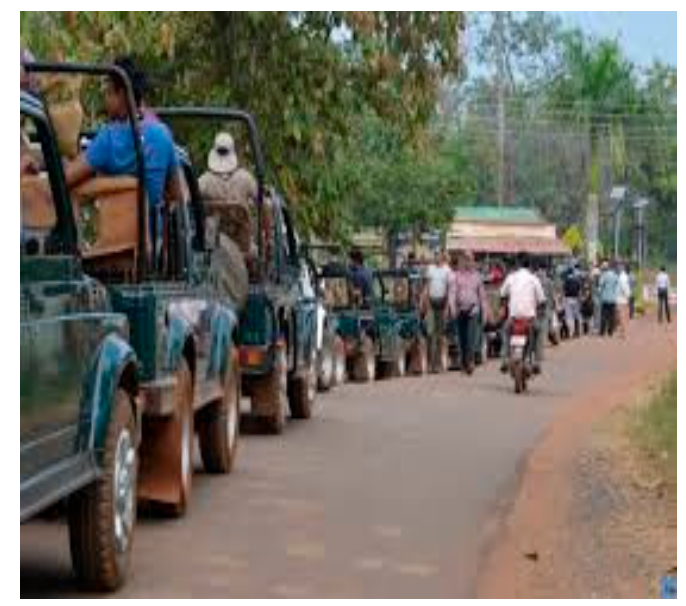

Figure 2. Tourists waiting to get into CTR, Ramnagar, on 28 June 2016 (photo by author).

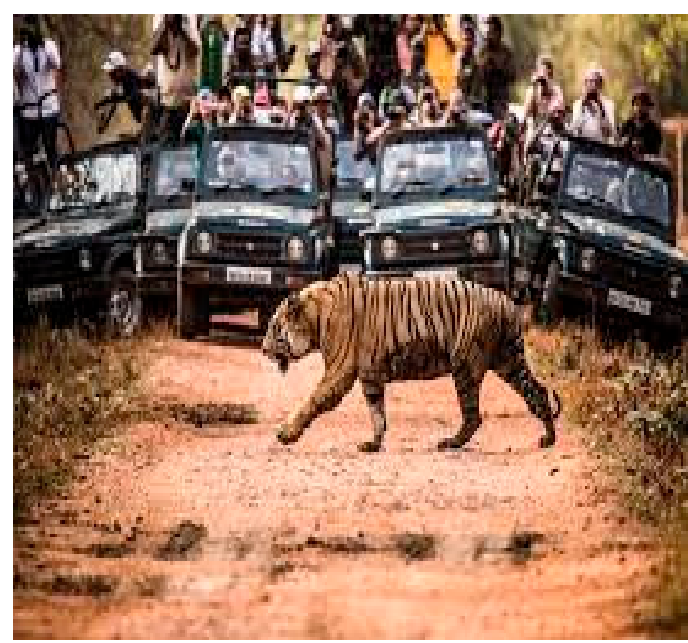

Figure 3. Tourists converging for tiger sighting in CTR, Ramnagar, on 29 June 2016 (photo by author).

The Royal Bengal tiger is a highly endangered species, and tourists who encountered the special species expressed a high level of awe and appreciation. Confirming this belief, a senior administrative officer at Ramnagar forest division mentioned: "Tourists just want to see a tiger, and they do not seem 
to have a lot of appreciation for other wildlife and forest and routinely break environmental laws. Moreover, the frequency with which accused is penalized are generally low except issuance of minor penalties. There is just one ticket issued in 15 days or so. Once out, they behave as if they are in a resort on the outskirts of Delhi and forget about the legacy of Corbett" (interview participant \# 23).

Owing to a lack of environmental awareness, tourists approached for this study derived contentment only with spotting a tiger. If some respondents did not detect a tiger, they were highly dissatisfied with their visit and did not seem to attach much importance to the forest or other animals. A visibly unhappy tourist stated: "I am never coming back, spent a lot and my children did not even see the tiger, what a waste" (focus group participant \# 3).

Another tourist mentioned: "Visiting CTR is not cheap, a family of 4 would roughly spend approximately Rs. 4000 (roughly \$US 60) towards hiring a vehicle and the services of a driver and guide to go inside the park. It is a lot of money for an average salaried person, and hence I demand more time inside the park" (interview participant \# 21).

A resident shared: "Littering is seen as a major problem at CTR, the biggest issue with littering is its negative effect on environmental aesthetics and the degradation of visitor experience" (interview participant \# 15).

A majority of tourists approached as part of the study inside the park did not seem to be aware of the impact of their detrimental actions on the environment and were openly indulging in deviant environmental behaviors.

\subsection{Environmental Transgressions}

A senior director at the Corbett foundation (local NGO) stated: "The increasing amount of litter, solid waste and garbage produced by a local shop and lodge owners have diminished the attractiveness of the region to tourists. Further, it also poses a significant environmental threat to human health and the fragile ecosystem of CTR, causing air, soil and water pollution" (interview participant \# 21).

Another resident who also worked as a local guide stated: "During the 2000s the accumulation of rubbish worsened dramatically due to the increasing number of resorts coming up" (interview participant \#14).

During the peak tourist season, CTR offers morning and evening safaris to approximately 600 tourists daily. However, with an average of 25 double-bed rooms per property and about 100 small and big hotels, CTR can accommodate 5000 tourists daily. Average high-season occupancy translates to 1500 tourists a day-almost three times the number that can enter the reserve. While drawing tourists on its name, a majority of resorts around Corbett, claiming to promote sustainable tourism management, have little to do with conserving nature. A senior administrative officer at Ramnagar forest division, while sharing her concern, stated: "Most resorts around CTR are party destinations. Resorts have leveled the land-shorn off shrubs and forest cover by the riverside and extended their gardens right up to the river even though clear norms are prohibiting any construction within 500 meters from the riverine systems. Worse, some resorts have even diverted river flows so that their properties can boast of being riverfront" (interview participant \# 23).

This study revealed that even though stakeholders (especially tourism providers) seem to be mindful of environmental transgressions, concrete efforts to promote sustainable tourism development does not seem to be a priority.

A local shop owner mentioned: "Why is there not a ban on the sale of disposable water bottles and plastic bags in and around CTR?" (interview participant \# 05).

During the focus group discussion, most respondents demanded more proactive participation of local authorities and tourism providers in reducing environmental transgressions outside CTR boundaries. A high-ranked forest official expressed his frustration by stating the following: "Government needs to define land use pattern around CTR, Kosi river and corridors and strict implementation of Eco-Sensitive Zone around tiger reserve are required to send out a message to the business owners and tourists on the sanctity of the place" (focus group participant \# 10). 
A forest officer stated: “There is no 'sustainable tourism' guideline in place, although wildlife wardens of national parks have control over the admission and regulation of tourists, the lack of guidelines leaves room for discretion and associated issues. Moreover, the Wildlife Protection Act mentions that wildlife habitat must not be disturbed. Earlier, there were very few people visiting sanctuaries, but now, wildlife safaris have exponentially increased. In such a scenario, we need to regulate it by increasing the fare of attending CTR and strictly moderating tourist numbers" (interview participant \# 25).

The director of a local NGO stated: "Outside the park, every care should be taken to ensure minimum noise pollution from diesel vehicles with strict enforcement by the police. Every effort must be made to promote Compressed Natural Gas CNG vehicles or those using bio-fuels. Authorities should demolish illegal encroachments and penalties should be imposed on hotels and restaurants for illegal construction and inappropriate waste disposal" (interview participant \# 21).

Both World Wildlife Fund (WWF) and the Corbett Foundation (a local NGO) were locally active and involved in a training and sensitization program of resort employees regarding the legacy of CTR and its ecological needs. "Since the majority of drivers, guides and hotel front line staff are recruited from the region, these locals could be trained as guides and custodians to educate tourists and support local tourism providers towards safeguarding the environment" stated a senior WWF official (interview participant \# 24).

\section{Conclusions and Recommendations}

This study investigates tourists' environmental transgressions while revealing the attitude and behavior of tourists toward the park under study. Consequently, the following recommendations are rendered to assuage the issue of environmental transgressions.

In response to the turmoil in tourism development, as custodians of national parks and its adjoining areas, the local authorities should not allow any new construction in the ecologically sensitive vicinity of CTR, and action should be taken against illegal, unauthorized activities at holiday resorts. Local authorities should adopt conservationist views, leading to restrictions on tourism development and putting in place harsher restrictions on the number of vehicles that can operate in and around CTR. Heavy penalties should be imposed on businesses that are habitual offenders and do not readily lend themselves to pro-environmental influences [68]. Professional planning and commitment towards tourism infrastructure development on the part of local authorities could go a long way toward reducing environmental transgressions.

About the tourist's attitudes, priority needs to be given towards transformation of tourists' attitudes, from 'individuals' just seeking thrill and leisure to 'eco-tourists' who leave national parks with an appreciation for the environment and iconic species. In this regard, in line with the current literature, this study finds the visitors' lived experiences can play a significant role in effectively altering visitor knowledge and behavior. Therefore, the park should stage the tourist experience as one that tourists are visiting an iconic tourist destination that is a national treasure; thus, the responsibility of exhibiting environmental compliance falls on them [69,70]. Similarly, as suggested by Ballantyne, Packer, and Hughes [71], wildlife tourism management practices that enlist tourists as conservation partners, communicate the reasons behind any constraints imposed, and present a consistent message regarding interactions with wildlife are likely to be successful in reducing environmental transgressions.

Further, evoking an emotional bond (i.e., place attachment) with the park is a viable way to curb a tourist's environmental transgression. Likely, tourists are not able to establish an emotional bond with the park after spending just two to three hours inside the park [40]. This study finds that returned tourists have developed an attachment to the park by experiencing a sense of awe and appreciation for nature during their multiple visits to the park. Hence, it is vital to strengthen the communicative message about the park's conservation efforts on the ecosystem to allow tourists to utilize the best of the resources provided by the park, which, consequently, will boost the tourist's attachment to the park. 
In regard to deviant tourist behavior, in agreement with the literature, respondents also confirm that to reduce deviant behaviors, the number of tourists needs to be regulated. However, respondents are also of the opinion that time allowed inside the park should be relaxed to enhance appreciation for nature and place attachment [72]. Historically, the Indian society has been known to have immense respect for nature [73]. Since deviant behavior is generally caused due to ignorance of laws and lack of social pressures, it could be countered by offering guidelines or codes of conduct for tourists through effective communication that informs tourists of the negative health consequences of these actions. Furthermore, the local tourism business community should establish its corporate social responsibility to prevent environmental transgressions effectively. For example, tour guides should play a proactive role in decreasing tourists' environmental transgressions in the park. Meanwhile, park staffs must strictly prohibit littering in and around CTR by issuing penalties against littering, and they should have more display/message boards and interpretation centers to enhance environmental awareness amongst tourists $[23,41]$.

While more overt enforcement could be applied to address behaviors inside national parks, complementary efforts could begin in private hotels and guest houses outside CTR [74]. A practical institutional framework and formulation of comprehensive policy and legislation could ensure local tourism providers' compliance with prescribed rules and guidelines [57]. Since most local tourism providers seem to be environmental offenders, policymakers need to introduce a new destination development strategy that promotes ethical and 'uncompromised' development by bringing the entire CTR region under strict environmental regulations and by enforcing sustained vigilant monitoring [50]. Similarly, legislation for diverting a specific proportion of profits made by businesses into local conservation efforts may also support countering environmental degradation [75]. Further tourism development should be geared toward community-based operations in which the community plays a central role in scrutinizing its progress.

Based on research themes emerging from this study, a framework for strategic transformation towards the reduction of environmental transgression is presented in Figure 4. Park authorities, the local municipality, local tourism providers, communities, and tourists have been identified as critical stakeholders that must contribute towards a reduction in environmental transgressions. Based on the findings, as CTR management and village residents share a preference for low-impact tourism, in the long run, it may be useful to examine the possible strategy of tourism being managed by an autonomous agency with the support of community-based institutions, the forest department, and NGOs [76,77]. Additionally, results also point towards strengthening locally active NGOs to escalate their environmental advocacy efforts towards reducing negative impacts of tourism activities in and around CTR [3,78].

This work has a specific limitation that should be taken into account: because of cost limitations, the chosen methodology only evaluated a small sample of tourists and stakeholders in a particular destination, namely CTR, India. In future survey-based works, it would be of value to seek greater generalization of the results by selecting other destinations, combined with a different typology of tourists and stakeholders. Future research directions could focus on model building, clustering, and ranking significant variables associated or correlated with the interaction between tourists, local tourism managers, and government agencies with regards to unsustainable tourism management in and around Indian national parks. 
Interventions

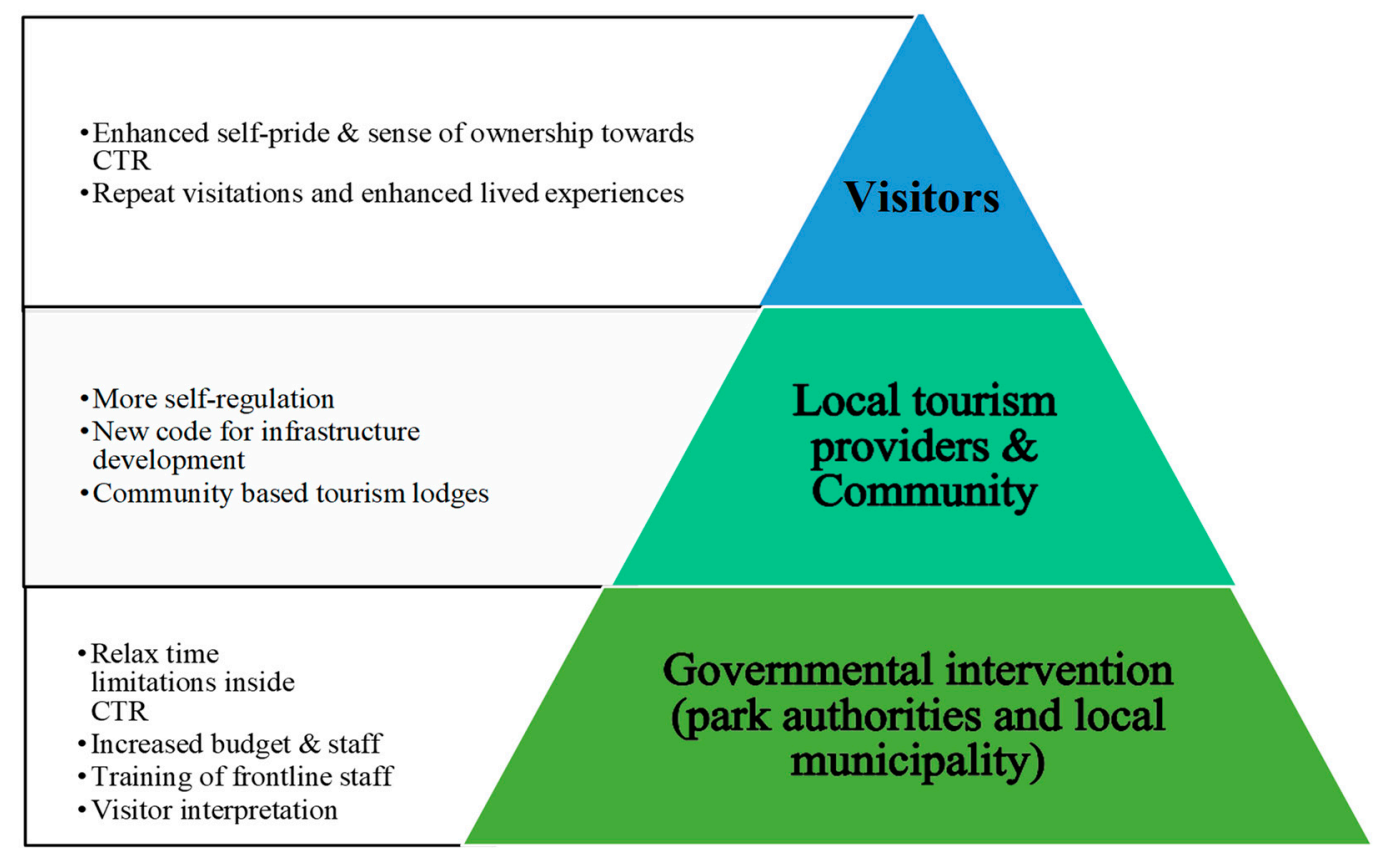

Figure 4. Framework for reducing environmental transgressions at CTR.

Author Contributions: The authors' contribution to this article is highlighted as follows. T.S. conducts the field investigation, analyzes the data, and drafts the manuscript; J.S.C. contributes to data analysis and the conclusion; and W.-Y.L. acts as a corresponding author working on the conclusion and revising the draft.

Funding: This research received no external funding.

Conflicts of Interest: The authors declare no conflicts of interest.

\section{References}

1. Prakash, O. Wildlife destruction: A legacy of the colonial state in India. In Proceedings of the Indian History Congress; Indian History Congress: Pune, India, 2006; Volume 67, pp. 692-702.

2. Guha, R. Radical American Environmentalism and Wilderness Preservation: A Third World Critique. In Varieties of Environmentalism; Guha, R., Martinez-Alier, J., Eds.; Essays North and South: London, UK, 1997.

3. Karanth, K.; DeFries, R. Nature-based tourism in Indian protected areas: New challenges for park management. Conserv. Lett. 2011, 4, 137-149. [CrossRef]

4. Gurung, C.P.; DeCoursey, M. The Annapurna Conservation Area Project: A Pioneering Example of Sustainable Tourism. In Cater Ecotourism: A Sustainable Option? John Wiley \& Sons: Chichester, UK, 1994.

5. Johannesen, A.B.; Skonhoft, A. Tourism, poaching and wildlife conservation: What can integrated conservation and development projects accomplish? Resour. Energy Econ. 2005, 27, 208-226. [CrossRef]

6. Higginbottom, K.; Green, R.; Northrope, C. A framework for managing the negative impacts of wildlife tourism on wildlife. Hum. Dimens. Wildl. 2003, 8, 1-24. [CrossRef]

7. Banerjee, A. Is wildlife tourism benefiting Indian protected areas? A survey. Curr. Issues Tour. 2012, 15, 211-227. [CrossRef]

8. Bandura, A.; Caprara, G.V.; Zsolnai, L. Corporate transgressions through moral disengagement. J. Hum. Values 2000, 6, 57-64. [CrossRef]

9. Martín, A.M.; Hess, S.; Alonso, I.; Frías-Armenta, M. Do lay people classify environmental transgressions in the same way as public administrations? Psyecology 2011, 2, 179-192. [CrossRef]

10. Solomon, J.N.; Gavin, M.C.; Gore, M.L. Detecting and understanding non-compliance with conservation rules. Biol. Conserv. 2015, 189, 1-4. [CrossRef]

11. Brown, T.J.; Ham, S.H.; Hughes, M. Picking up litter: An application of theory-based communication to influence tourist behavior in protected areas. J. Sustain. Tour. 2010, 18, 879-900. [CrossRef] 
12. Hannam, K.; Diekmann, A. Tourism and India: A Critical Introduction; Routledge: London, UK, 2010; p. 75.

13. Subramanian, S. India Has Two Weeks to Solve the Tiger vs Tourism Dilemma. Available online: https: //www.thenational.ae/world/asia/india-has-two-weeks-to-solve-the-tiger-vs-tourism-dilemma-1.403634 (accessed on 10 July 2017).

14. Sharpley, R. Rural tourism and the challenge of tourism diversification: The case of Cyprus. Tour. Manag. 2002, 23, 233-244. [CrossRef]

15. Duffy, R. The Politics of Ecotourism and the Developing World. J. Ecotour. 2006, 5, 1-6. [CrossRef]

16. Hernández, B.; Martín, A.M.; Ruiz, C.; Hidalgo, M.C. The role of place identity and place attachment in breaking environmental protection laws. J. Environ. Psychol. 2010, 30, 281-288. [CrossRef]

17. Semeniuk, C.A.; Haider, W.; Cooper, A.; Rothley, K.D. A linked model of animal ecology and human behavior for the management of wildlife tourism. Ecol. Model. 2010, 221, 2699-2713. [CrossRef]

18. Pickering, C.M.; Hill, W. Impacts of recreation and tourism on plant diversity and vegetation in protected areas in Australia. J. Environ. Manag. 2007, 85, 791-800. [CrossRef]

19. Geneletti, D.; Van Duren, I. Protected area zoning for conservation and use: A combination of spatial multicriteria and multi-objective evaluation. Landsc. Urban Plan. 2008, 85, 97-110. [CrossRef]

20. Esfandiar, K.; Dowling, R.; Pearce, J. Pro-environmental behaviour in national parks: Smart for one, but dump for all. In CAUTHE 2018: Get Smart: Paradoxes and Possibilities in Tourism, Hospitality and Events Education and Research; Young, T., Stolk, P., McGinnis, G., Eds.; Newcastle Business School, The University of Newcastle: Newcastle, Australia, 2018; pp. 741-744.

21. Hu, H.; Zhang, J.; Wang, C.; Yu, P.; Chu, G. What influences tourists' intention to participate in the Zero Litter Initiative in mountainous tourism areas: A case study of Huangshan National Park, China. Sci. Total Environ. 2018, 657, 1127-1137. [CrossRef]

22. Dawson, C.P.; Hendee, J.C.; Schuster, R.M. Wilderness visitor management: Stewardship for Quality Experiences. In Wilderness Management: Stewardship and Protection of Resources and Values, 4th ed.; Fulcrum Publishing: Golden, CO, USA, 2009.

23. Frost, W.; Laing, J.; Beeton, S. The Future of Nature-Based Tourism in the Asia-Pacific Region. J. Travel Res. 2014, 53, 721-732. [CrossRef]

24. Wolf, D.I.; Stricker, H.K.; Hagenloh, G. Outcome-focused national park experience management: Transforming participants, promoting social well-being, and fostering place attachment. J. Sustain. Tour. 2015, 23, 358-381. [CrossRef]

25. Kollmuss, A.; Agyeman, J. Mind the Gap: Why do people act environmentally and what are the barriers to pro-environmental behavior? Environ. Educ. Res. 2002, 8, 239-260. [CrossRef]

26. Budruk, M.; Thomas, H.; Tyrrell, T. Urban green spaces: A study of place attachment and environmental attitudes in India. Soc. Nat. Resour. 2009, 22, 824-839. [CrossRef]

27. Coghlan, A.; Castley, G. A matter of perspective: Residents', regulars' and locals' perceptions of private tourism eco-lodge concessions in Kruger National Park, South Africa. Curr. Issues Tour. 2013, 16, $682-699$. [CrossRef]

28. Halpenny, E.A. Pro-environmental behaviors and park visitors: The effect of place attachment. J. Environ. Psychol. 2010, 30, 409-421. [CrossRef]

29. Kyle, G.; Graefe, A.; Manning, R.; Bacon, J. An examination of the relationships between leisure activity involvement and place attachment among hikers along the Appalachian Trail. J. Leis. Res. 2003, 35, $249-273$. [CrossRef]

30. Williams, D.; Vaske, J. The measurement of place attachment: Validity and generalizability of a psychometric approach. For. Sci. 2003, 49, 830-840.

31. Ramkissoon, H.; Weiler, B.; Smith, L. Place attachment and pro-environmental behavior in national parks: The development of a conceptual framework. J. Sustain. Tour. 2012, 20, 257-276. [CrossRef]

32. Zelenski, J.; Dopko, R.; Capaldi, C. Cooperation is in our nature: Nature exposure may promote cooperative and environmentally sustainable behavior. J. Environ. Psychol. 2015, 42, 24-31. [CrossRef]

33. Seamon, D. Place attachment and phenomenology: The synergistic dynamism of place. In Place Attachment: Advances in Theory, Methods, and Applications; Manzo, L.C., Devine-Wright, P., Eds.; Routledge: London, UK; New York, NY, USA, 2013.

34. Hidalgo, M.C.; Hernandez, B. Regular Article: Place Attachment: Conceptual and Empirical Questions. J. Environ. Psychol. 2001, 21, 273-281. [CrossRef] 
35. Serenari, C.; Leung, Y.; Attarian, A.; Franck, C. Understanding environmentally significant behavior among whitewater rafting and trekking guides in the Garhwal Himalaya, India. J. Sustain. Tour. 2012, 20, 757-772. [CrossRef]

36. Payton, M.; Fulton, D.; Anderson, D. Influence of place attachment and trust on civic action: A study at Sherburne National Wildlife Refuge. Soc. Nat. Resour. 2007, 18, 511-528. [CrossRef]

37. Morgan, P. Towards a developmental theory of place attachment. J. Environ. Psychol. 2010, 30, 11-22. [CrossRef]

38. Gifford, R.; Andreas, N. Personal and social factors that influence pro-environmental concern and behavior: A review. Int. J. Psychol. 2014, 49, 141-157.

39. Lee,H.T. How recreation involvement, place attachment and conservation commitment affect environmentally responsible behavior. J. Sustain. Tour. 2011, 19, 895-915. [CrossRef]

40. Toudert, D.; Bringas-Rabago, N. Exploring the impact of destination attachment on the intentional behavior of the US visitors familiarized with Baja California, Mexico. Curr. Issues Tour. 2015, 21, 805-820. [CrossRef]

41. Buta, N.; Holland, S.M.; Kaplanidou, K. Local communities and protected areas: The mediating role of place attachment for pro-environmental civic engagement. J. Outdoor Recreat. Tour. 2014, 5, 10. [CrossRef]

42. Zhang, Y.; Zhang, H.L.; Zhang, J.; Cheng, S. Predicting residents' pro-environmental behaviors at tourist sites: The role of awareness of disaster's consequences, values, and place attachment. J. Environ. Psychol. 2014, 40, 131-146. [CrossRef]

43. Singh, S. Destination development dilemma-Case of Manali in Himachal Himalaya. Tour. Manag. 2008, 29, 1152-1156. [CrossRef]

44. Briassoulis, H. Sustainable tourism and the question of the commons. Ann. Tour. Res. 2002, 29, 1065-1085. [CrossRef]

45. Middleton, V.T.; Hawkins, R. Sustainable Tourism: A Marketing Perspective; Routledge: London, UK, 1998.

46. Hunter, C. Sustainable tourism as an adaptive paradigm. Ann. Tour. Res. 1997, 24, 850-867. [CrossRef]

47. Saarinen, J. Traditions of sustainability in tourism studies. Ann. Tour. Res. 2006, 33, 1121-1140. [CrossRef]

48. Branwell, B.; Lane, B. Sustainable tourism: An evolving global. J. Sustain. Tour. 1993, 1, 1-5. [CrossRef]

49. Walpole, M.J.; Goodwin, H.J. Local economic impacts of dragon tourism in Indonesia. Ann. Tour. Res. 2000, 27, 559-576. [CrossRef]

50. Gardner, J.; Sinclair, J.; Berkes, F.; Singh, R.B. Accelerated tourism development and its impacts in Kullu-Manali, HP, India. Tour. Recreat. Res. 2002, 27, 9-20.

51. Kuniyal, J.C. Solid waste management in the Himalayan trails and expedition summits. J. Sustain. Tour. 2005, 13, 391-410. [CrossRef]

52. Rastogi, A.; Hickey, G.M.; Badola, R.; Hussain, S.A. Understanding the local socio-political processes affecting conservation management outcomes in Corbett Tiger Reserve, India. Environ. Manag. 2014, 53, 913-929. [CrossRef] [PubMed]

53. Harrison, L.C.; Jayawardena, C.; Clayton, A. Sustainable tourism development in the Caribbean: Practical challenges. Int. J. Contemp. Hosp. Manag. 2003, 15, 294-298. [CrossRef]

54. Telfer, D.; Sharpley, R. Tourism and Development in the Developing World; Routledge: Abingdon, UK, 2008.

55. Jhala, Y.V.; Gopal, R.; Qureshi, Q. (Eds.) The Status of Tigers, Co-Predators and Prey in INDIA 2014; National Tiger Conservation Authority: New Delhi, India; Wildlife Institute of India: Dehradun, India, 2015.

56. Badola, R.; Hussain, S.A.; Mishra, B.K.; Konthoujam, B.; Thapliyal, S.; Dhakate, P.M. An assessment of ecosystem services of Corbett Tiger Reserve, India. Environmentalist 2010, 30, 320-329. [CrossRef]

57. Rastogi, A.; Badola, R.; Hussain, S.A.; Hickey, G.M. Assessing the utility of stakeholder analysis to protected areas management: The case of Corbett National Park, India. Biol. Conserv. 2010, 143, 2956-2964. [CrossRef]

58. Gusain, R. Tourist Numbers at All-Time High in Corbett Park. Daily Mail. Available online: http://www.dailymail.co.uk/indiahome/indianews/article-3065580/Corbett-National-Park-Touristnumbers-time-high-Corbett-park.html (accessed on 10 August 2017).

59. Sautter, E.T.; Leisen, B. Managing stakeholders a tourism planning model. Ann. Tour. Res. 1999, 26, 312-328. [CrossRef]

60. Glaser, B.G.; Strauss, A.L. The Discovery of Grounded Theory: Strategies for Qualitative Research; Aldine: Chicago, IL, USA, 1967.

61. Bernard, H.R. Social Research Methods: Qualitative and Quantitative Approaches, 2nd ed.; SAGE Publishing: Thousand Oaks, CA, USA, 2013; p. 175. 
62. Boddy, C.R. Sample size for qualitative research. Qual. Mark. Res. 2005, 19, 426-432. [CrossRef]

63. Creswell, J.W. Qualitative Inquiry and Research Design: Choosing among Five Traditions; SAGE: London, UK, 1998.

64. Creswell, J.W. Qualitative Inquiry E Research Design: Choosing among Five Approaches, 3rd ed.; SAGE Publishing: Thousand Oaks, CA, USA, 2013.

65. Ray, M.A. The richness of phenomenology: Philosophic, theoretic and methodologic concerns. In Critical Issues in Qualitative Research Methods; Morse, J.M., Ed.; SAGE Publishing: Thousand Oaks, CA, USA, 1994; pp. 117-133.

66. Miles, M.B.; Huberman, A.M. Qualitative Data Analysis: An Expanded Sourcebook; SAGE Publishing: Thousand Oaks, CA, USA, 1994.

67. Merriam, S.B. Qualitative Research: A Guide to Design and Implementation; John Wiley \& Sons: San Francisco, CA, USA, 2009.

68. Gupta, S. The role of the judiciary in promoting sustainable development: Need for specialized environment court in India. J. Sustain. Dev. 2011, 4, 249. [CrossRef]

69. Kajan, E. Community perceptions to place attachment and tourism development in Finnish Lapland. Tour. Geogr. 2014, 16, 490-511. [CrossRef]

70. Marion, J.; Reid, S. Minimizing visitor impacts to protected areas: The efficacy of low impact education programs. J. Sustain. Tour. 2007, 15, 5-27. [CrossRef]

71. Ballantyne, R.; Packer, J.; Hughes, K. Tourists' support for conservation messages and sustainable management practices in wildlife tourism experiences. Tour. Manag. 2009, 3, 658-664. [CrossRef]

72. Scannell, L.; Gifford, R. Place attachment enhances psychological need satisfaction. Environ. Behav. 2017, 49, 359-389. [CrossRef]

73. Callicot, J.B.; Ames, R.T. Nature in Asian Traditions of Thought: Essays in Environmental Philosophy; SUNY Press: Albany, NY, USA, 1989.

74. Burns, G.L.; Howard, P. When wildlife tourism goes wrong: A case study of stakeholder and management issues regarding Dingoes on Fraser Island, Australia. Tour. Manag. 2003, 24, 699-712. [CrossRef]

75. Tosun, C. Limits to community participation in the tourism development process in developing countries. Tour. Manag. 2000, 21, 613-633. [CrossRef]

76. Zeppel, H. Collaborative governance for low-carbon tourism: Climate change initiatives by Australian tourism agencies. Curr. Issues Tour. 2011, 15, 603-626. [CrossRef]

77. Plummer, R.; Fennell, D.A. Managing protected areas for sustainable tourism: Prospects for adaptive co-management. J. Sustain. Tour. 2009, 17, 149-168. [CrossRef]

78. Sinha, B.C.; Qureshi, Q.; Uniyal, V.K.; Sen, S. Economics of wildlife tourism-Contribution to livelihoods of communities around Kanha Tiger Reserve, India. J. Ecotour. 2012, 11, 207-218. [CrossRef] 